\title{
谈农村水利工程建设与运行管理体制机制改革
}

孙庆龙

内蒙古科右前旗巴日嘎斯台乡

DOI:10.32629/eep.v3i1.607

[摘 要] 农村水利工程的建设是推动农业进步, 提高农村经济水平的重要措施, 不过随着农村建设步伐的加快,农村水利工程建设与运行管理机 制中存在的问题也逐渐显露出来, 若想改进农村水利工程建设质量,推动农村经济的增长,开展管理机制的改革势在必行。文章主要对农村水利 工程建设与运行管理体制改革进行详细分析。

[关键词] 农村水利工程; 建设与运行管理体制; 改革

随着社会经济体制改革的深入, 我国农业发展也面临着新的问题和挑 战, 农村水利工程在农业经济发展中起着非常重要的作用, 做好水利工程 管理能够更好的发挥出水利工程作用。不过现阶段农村水利工程建设与运 营管理体制中还存在部分不足, 需要对体制进行改革, 进而在保证农民经 济收入的基础上, 促进农业经济增长。

\section{1 农村水利工程建设意义}

1. 1 有利于改善农业发展环境

农村在我国的占地面积较大, 由于区域的不同, 自然资源也会存在较大 差异, 对于一些干旱少雨、水资源紧缺的区域来说, 水利工程的建设可增大水 资源利用率, 进而为农作物的生长营造良好环境, 提高区域农业经济水平。

1.2 是实现社会主义新农村建设目标的重要措施

对于农村来说, 其水利工程建设形式相对较多, 水库、堤坝、水井等建 设形式都属于农村水利工程的一种, 这些水利工程的建设优化了农村蓄水 与引水的功能, 保证农作物灌溉效率, 加快农作物的生长, 从而增大农民的 经济收入。

\section{2 农村水利工程建设与运行管理中的问题}

2. 1 缺少良性运行机制

一方面是由于产权机制改革落实不到位, 产权管理制度不完善, 产权 主体划分不明确, 管理工作的开展受到诸多阻碍。另一方面是由于管护考 核机制的缺失, 管护工作的开展受到制约, 再加上管护能力不足, 影响了整 体管理效果。

\section{2 产权性质不清晰}

改革开放前, 农村水利工程建设是由政府部门及农村自筹扶持下开展 的, 建成后的产权自然也是归政府及群众所有, 不过在改革开放后, 农村经 济体制发生了较大变化, 尤其是在承包制落实后, 农村的经济运营从原有 的集中管理转变成分户管理, 这使得农村水利工程建设后产权划分存在模 糊现象, 工程管理人员划分不明确, 阻碍了管理工作的有序开展。且随着农 村经济体制改革的不断深入, 这一问题将会越来越明显, 如果不能对产权问 题进行清晰化处理, 将会直接影响农村水利工程建设, 阻碍农村经济增长。

2.3 水利设施投资力度不足

鉴于水利工程建设对农村农业经济的发展的影响, 应加大资金投放, 提高工程建设质量, 促进其性能的发挥。不过从目前农村水利设施建设实 际情况来看, 因地方政府自身财政资金有限, 在农村水利设施建设中的投 资不足, 这一现象导致农村水利工程建设中, 资源及人力投入不高, 严重阻 碍了工程建设作业的开展, 降低了水利工程的建设质量, 对农业经济发展 带来了较大影响。

\section{3 农村水利工程建设与运行管理体制的改革思路}

一是以政府为主导, 加大社会参与力度, 构建完善的管理体系。转变政
府职能, 在现有管理制度的基础上,结合农村发展实况不断完善管理体制 内容, 制定合理的鼓励政策, 以提高社会参与力度, 健全管理体系, 对农村 水利工程的建设及正常运行提供保障。同时, 在管理体系中, 还要对各参与 方的权利予以明确划分, 确保管理工作的高效落实。

二是建立健全的投融资管理体制。先对现有的财政收支结构实行调整, 扩展资金筹集渠道, 加大融资力度, 为水利工程建设提供保障。之后制定鼓 励措施, 吸引更多社会资本的参与, 并通过惠民政策、水价改革等的落实, 为这些社会企业提供优惠政策, 调动其参与的积极性, 提升农村水利工程 建设效率。最后, 对现有金融产品予以创新和优化, 从信贷、保险等多方面 为水利工程建设提供保障。

三是做好权责划分, 建立科学的组织实施方式。国家水利部门应根据 农村水利工程建设现状, 制定科学合理的管理政策及标准, 并落实到实际 工作中, 划分管理权责, 对农村现有水利项目实行科学评估, 了解其运行情 况, 且开展翻新重建工作, 以提高水利工程质量。结合农村水利工程规模、 特征, 在监管一体理念的引导下, 构建专业的组织规划团队, 确定项目组织 法人, 因地制宜的开展水利工程修建工作, 以此提高水利工程建设质量, 增 大资源利用率。

四是构建多样化的管理模式。建立社会化、市场化、集中化的管理模 式; 将传统的以事定费转变成竞争购买或委托购买的方式, 且通过签订承 包及委托合同的方式, 对水利工程施工企业进行管理和控制; 内部通过构 建村民合作组织形成工程建设的自管模式。

五是完善资金保障机制。对农村水利工程建设资金实行科学管理, 确保 资金的充足性, 扩展资金融资渠道, 利用分包经营的模式降低资金投入风险。

六是构建监督管理考核机制。结合农村实际情况制定科学合理的监督 管理考核机制, 对水利工程建设流程实行科学管控, 对运营管理内容予以 审查和追责, 并通过公开平台的建立, 将资金使用情况予以公布, 实现透明 化管理。

\section{4 结语}

综上所述, 当前, 我们必须改变农村水利工程建设及运营管理理念, 创 新运营管理机制, 有效解决现存的体制不顺、机制不灵活、运行效果不佳等 问题, 以此彻底提高农村水利工程建设质量, 发挥出水利设施的最大作用。

\section{[参考文献]}

[1]王维庆.农村水利工程建设中存在的问题及建议 [J].乡村科 技,2019,(28):119+121.

[2]刘刚燕. 农村水利工程建设与管理问题研究 [J]. 农业与技 术,2019,39(15):64-65.

[3]岳志强. 农村水利工程建设存在问题和解决措施 [J]. 内蒙古水 利,2018,(02):38-39. 